\title{
LARVICIDAL EFFECTS OF SOME PLANT SEED EXTRACTS ON Anopheles annularis Vander Wulp AND Culex quinquefasciatus Say (DIPTERA: CULICIDAE)
}

\author{
Nasiruddin, M., M. A. Azadi ${ }^{1}$, M. R. Chowdhury and R. A. H. Tonni \\ Department of Zoology, University of Chittagong, Chattogram-4331, Bangladesh; ${ }^{1}$ International \\ Islamic University, Chattogram-4318, Bangladesh
}

\begin{abstract}
Larvicidal effects of distilled water, 50\% ethyl alcohol, acetone and methanol extracts on seed of four plants viz. Sinapis alba (Linn.), Carica papaya (Linn.), Momordica charantia (Linn.) and Capsicum annuum (Linn.) were studied upon the mosquito larvae of Anopheles annularis Vander Wulp and Culex quinquefasciatus Say under normal laboratory conditions with average temperature and relative humidity of $31.1^{\circ} \mathrm{C}$ and $57.6 \%$, respectively. Percentage mortality, probit mortality, chi-square and ANOVA values for the larvae, extracts and concentrations were calculated for 24 hours exposure period. Mortality was dose dependent. The values of $\mathrm{LC}_{50}$ of the seeds of $S$. alba on An. annularis at the application doses for the distilled water, 50\% ethyl alcohol, acetone and methanol extracts were $3431.791,1038.363,1254.810$ and 2269.975 ppm, respectively; for C. papaya were 804.008, 403.294, 597.165 and 573.241 ppm, respectively; for M. charantia were 10593.241, 5017.710, 5650.191 and 6075.204 ppm, respectively; and for $C$. апnиum were 1274.968, 4637.201, 1604.852 and 1905.692 ppm, respectively. The values of $\mathrm{LC}_{50}$ of $S$. alba seeds on $C x$. quinquefasciatus at the application doses for the distilled water, 50\% ethyl alcohol, acetone and methanol extracts were 1415.311, 432.996, 569.701 and $770.250 \mathrm{ppm}$, respectively; for $C$. papaya were $705.599,385.688,341.003$ and 481.067 ppm, respectively; for $M$. charantia were 7764.154, 4496.464, 5353.759 and $5825.031 \mathrm{ppm}$, respectively; and for C. аппиит were $2173.631,1311.538,78.748$ and 182.869 ppm, respectively. Of the four plant seed extracts, $C$. papaya seed extracts were the most toxic for both the mosquito species.
\end{abstract}

Key words: Larvicide; Seed extracts; $\mathrm{LC}_{50}$; Anopheles annularis; Culex quinquefasciatus.

\section{INTRODUCTION}

Mosquitoes are the most prominent group of insects belonging to the order Diptera. They are small, midge-like flies which comprise the family Culicidae. In Bangladesh, altogether 113 species including 34 Anophelins and 79 Culicins have so far been recorded by different workers (Ahmed 1987). The females of many species of mosquitoes are blood sucking and vectors of some dangerous diseases, such as malaria, dengue fever, filariasis, schistosomiasis and Japanese encephalitis. Mosquito-borne diseases have an economic impact, including loss in commercial and labor particularly in countries with tropical and sub-tropical climates.

Mosquito control is a difficult task and is becoming even more so due to a variety of factors including the development of insecticidal resistance and concern over environmental pollution and many of them are immune suppressants. Historically, the most effective mosquito control is larvicides, applied directly to water source.

The control of mosquito larvae worldwide depends primarily on continued applications of synthetic chemicals including organophophates. Plants are the promising alternative source for the control of insect pests to replace conventional synthetic insecticides because they bio-synthesize a diverse array of low molecular weight PSMs (Plant Secondary Metabolites) or specialized metabolites. Certain plant species have proved efficacy as larvicides against different species of mosquitoes (Mansour et al. 1998).

Studies have been reported on the toxicological effects of plant extracts on mosquito larvae around the world (Aina et al. 2009, Chanbunjong et al. 2010, El-Sheikh et al. 2011, Kamaraj et al. 2011, Shaktivadivel et al. 2012, Sasanti et al. 2014, Thangaraj et al. 2014). In Bangladesh, study on botanical control of mosquito larvae is limited. The available works on this aspect are those of Ameen et al. 
(1983a, b), Ameen et al. (1985), Hossain et al. (1998), Zannat et al. (2007), Nikkon et al. (2009), Bhuiyan (2013), Nika (2015), Khan et al. (2016, 2017) and Nasiruddin et al. (2018).

The present paper is directed particularly at determining the use of seed extracts of four plants, namely Sinapis alba (Linn.), Carica papaya (Linn.), Momordica charantia (Linn.) and Capsicum annuum (Linn.) in controlling mosquito larvae of Anopheles annularis Vander Wulp and Culex quinquefasciatus Say.

\section{MATERIAL AND METHODS}

The study was carried out in the Entomology Research Laboratory (Average temperature $31.1^{\circ} \mathrm{C}$ and average relative humidity 57.6\%) of Zoology Department, Chittagong University with a view to find out the larvicidal effects of seed extracts of four plants against the larvae of two mosquito species, Anopheles annularis and Culex quinquefasciatus.

\section{Preparation of seeds}

The seeds of the four plants, viz. Sinapis alba (English name: White mustard, Family: Brassicaceae), Carica papaya (English name: papaya, Family: Caricaceae), Momordica charantia (English name: bitter melon, Family: Cucurbitaceae), and Capsicum annuum (English name: chili pepper, Family: Solanaceae) were collected from local seed markets except $C$. papaya. For the experimental purpose, the experimental seeds were ground in an electric grinder, and the seed powder was sieved through a sieve of mesh size $0.0025 \mathrm{~cm}^{2}$.

\section{Maintenance of the experimental mosquito larvae}

Anopheles annularis and Culex quinquefasciatus larvae were collected from nearby small temporary rain pools and drains, respectively. The larvae were collected in a plastic bowl with a hand sieve and brought to the laboratory and then reared in a glass jar. Third or fourth instar mosquito larvae were obtained from the rearing jar. After being acclimatized in the laboratory condition, the healthy and fresh mosquito larvae were taken for experiments.

\section{Extraction of dry seeds and preparation of doses}

Ten grams of dry seed powder were extracted with $100 \mathrm{ml}$ of the distilled water, $50 \%$ ethyl alcohol, acetone and methanol solvents separately. For each solution required amount of dry seed powder was taken in a $500 \mathrm{ml}$ conical flask and required amount of solvent was poured into the flask and closed with a cork stopper. The flask was shaken vigorously for 3-4 hours on a magnetic stirrer to ensure maximum extraction of toxic components of the seed powder. After mixing, the resultant liquid was filtered through Whatman filter paper No. 1. The filtrate solution obtained was designated as 'Stock solution'. For each set of experiment a certain (calculated) volume of the stock solution was added to the certain volume of tap water so that final volume in the experimental beakers was always $250 \mathrm{ml}$ in each of the doses and replicates as suggested by APHA (2005).

\section{Bioassay}

The bioassays were run in 18 glass beakers, each containing $250 \mathrm{ml}$ of tap water and extract and run for a period of 24 hours. Five concentrations of each extract after preliminary screenings were taken in the final experiments. A set of ten mosquito larvae was released in each dose concentration; three replications were used for each dose concentration. The test mosquito larvae were exposed to the extracts for the stipulated exposure period. The beakers were netted on top. Larval mortality counts were taken after 24 hours. 


\section{Data analysis}

The data were analyzed statistically by probit analysis following Finney (1971) where $\mathrm{LC}_{50}$ values were calculated using a computer based probit analysis program. The values of chi-square $\left(\chi^{2}\right)$ were determined as suggested by Fisher and Yates (1963) using experimental data of expected and observed numbers killed and then compared with the tables of statistics for (n-1) degrees of freedom at $1 \%$ level of significance. One-way ANOVA was done and compared with the tables of statistics for (n-1) degrees of freedom at $1 \%$ level of significance.

\section{RESULTS}

The mosquito larvae were exposed to different concentrations of the experimental seed extracts and the achieved mortality range, the slope line equation, chi-square values, the ANOVA values of the different extracts are shown in Table 1 for An. annularis and Table 2 for Cx. quinquefasciatus larvae.

Table 1. Toxicities of the extracts of Sinapis alba, Carica papaya, Momordica charantia and Capsicum annuum seeds on Anopheles annularis larvae exposed for 24 hours.

\begin{tabular}{|c|c|c|c|c|c|c|c|}
\hline Seeds & Solvent & $\begin{array}{l}\text { Dose Range } \\
\text { (ppm) }\end{array}$ & $\begin{array}{c}\text { Mortality } \\
\text { Range }(\%)\end{array}$ & $\begin{array}{l}\text { Estimated } \\
\text { slope line } \\
\text { value }\end{array}$ & $\begin{array}{c}\text { Chi- } \\
\text { square } \\
\text { value }\end{array}$ & $\begin{array}{c}\text { ANOVA } \\
\text { value } \\
\text { (Treatment) }\end{array}$ & $\begin{array}{c}\text { ANOVA } \\
\text { value } \\
\text { (Replication) }\end{array}$ \\
\hline \multirow{8}{*}{ Sinapis alba } & \multirow{6}{*}{$\begin{array}{l}\text { Distilled } \\
\text { water } \\
50 \% \text { ethyl } \\
\text { alcohol } \\
\text { Acetone }\end{array}$} & \multirow[t]{2}{*}{$2000-6000$} & \multirow[t]{2}{*}{$16.67-96.67$} & \multirow[t]{2}{*}{$5.466 x-14.31$} & 22.100 & 46.138 & 1.116 \\
\hline & & & & & $\mathrm{P}<0.01$ & $\mathrm{P}<0.01$ & $P>0.01$ \\
\hline & & \multirow[t]{2}{*}{$500-1700$} & \multirow[t]{2}{*}{$10.00-96.67$} & \multirow[t]{2}{*}{$5.489 x-11.53$} & 19.079 & 95.830 & 1.217 \\
\hline & & & & & $\mathrm{P}<0.01$ & $\mathrm{P}<0.01$ & $\mathrm{P}>0.01$ \\
\hline & & \multirow[t]{2}{*}{$800-2000$} & \multirow[t]{2}{*}{$13.33-93.33$} & \multirow[t]{2}{*}{$6.323 x-14.61$} & 4.119 & 200.599 & 13.772 \\
\hline & & & & & $P>0.01$ & $\mathrm{P}<0.01$ & $\mathrm{P}<0.01$ \\
\hline & \multirow[t]{2}{*}{ Methanol } & \multirow[t]{2}{*}{ 2000-3000 } & \multirow{2}{*}{$23.33-96.67$} & \multirow{2}{*}{$10.13 x-28.72$} & 8.372 & 52.420 & 1.383 \\
\hline & & & & & $P>0.01$ & $\mathrm{P}<0.01$ & $P>0.01$ \\
\hline \multirow{8}{*}{$\begin{array}{l}\text { Carica } \\
\text { papaya }\end{array}$} & \multirow{6}{*}{$\begin{array}{l}\text { Distilled } \\
\text { water } \\
50 \% \text { ethyl } \\
\text { alcohol } \\
\text { Acetone }\end{array}$} & \multirow[t]{2}{*}{$350-1550$} & \multirow[t]{2}{*}{$13.33-93.33$} & \multirow[t]{2}{*}{$2.200 x-1.471$} & 17.120 & 92.272 & 2.363 \\
\hline & & & & & $\mathrm{P}<0.01$ & $\mathrm{P}<0.01$ & $\mathrm{P}>0.01$ \\
\hline & & \multirow{2}{*}{$150-950$} & \multirow{2}{*}{$13.33-93.33$} & \multirow{2}{*}{$3.374 x-3.793$} & 13.066 & 275.706 & 7.428 \\
\hline & & & & & $\mathrm{P}>0.01$ & $\mathrm{P}<0.01$ & $\mathrm{P}>0.01$ \\
\hline & & \multirow[t]{2}{*}{$200-1000$} & \multirow[t]{2}{*}{$6.67-83.33$} & \multirow[t]{2}{*}{$3.529 x-4.806$} & 9.030 & 70.249 & 0.167 \\
\hline & & & & & $\mathrm{P}>0.01$ & $\mathrm{P}<0.01$ & $\mathrm{P}>0.01$ \\
\hline & \multirow{2}{*}{ Methanol } & \multirow[t]{2}{*}{$250-1050$} & \multirow[t]{2}{*}{$13.33-86.67$} & $1.591 x-0.651$ & 31.670 & 78.670 & 1.550 \\
\hline & & & & & $\mathrm{P}<0.01$ & $\mathrm{P}<0.01$ & $P>0.01$ \\
\hline & Distilled & $9000-13000$ & $13.33-96.67$ & $13.15 x-48.16$ & 26.928 & 87.446 & 0.545 \\
\hline & water & & & & $\mathrm{P}<0.01$ & $\mathrm{P}<0.01$ & $\mathrm{P}>0.01$ \\
\hline & $50 \%$ ethyl & $4500-5700$ & $13.33-90.00$ & $8.908 x-27.76$ & 28.544 & 70.160 & 1.385 \\
\hline Momordica & alcohol & & & & $\mathrm{P}<0.01$ & $\mathrm{P}<0.01$ & $\mathrm{P}>0.01$ \\
\hline charantia & Acetone & $5000-6200$ & $13.33-80.00$ & $25.39 x-90.30$ & 8.709 & 107.670 & 2.153 \\
\hline & & & & & $\mathrm{P}>0.01$ & $\mathrm{P}<0.01$ & $P>0.01$ \\
\hline & Methanol & $5500-6700$ & $13.33-90.00$ & $18.21 x-63.92$ & 11.431 & 39.183 & 0.090 \\
\hline & & & & & $\mathrm{P}>0.01$ & $\mathrm{P}<0.01$ & $\mathrm{P}>0.01$ \\
\hline & Distilled & $1900-2500$ & $13.33-90.00$ & $19.9 x-61.44$ & 4.321 & 49.105 & 1.263 \\
\hline & water & & & & $\mathrm{P}>0.01$ & $\mathrm{P}<0.01$ & $\mathrm{P}>0.01$ \\
\hline & $50 \%$ ethyl & $1100-1500$ & $6.67-93.33$ & $19.08 x-54.47$ & 3.419 & 242.214 & 7.108 \\
\hline Capsicum & alcohol & & & & $\mathrm{P}>0.01$ & $\mathrm{P}<0.0 .01$ & $\mathrm{P}>0.01$ \\
\hline апnuиm & Acetone & $1400-1800$ & $6.67-96.67$ & $8 x-20.62$ & 57.935 & 137.858 & 2.250 \\
\hline & & & & & $\mathrm{P}<0.01$ & $\mathrm{P}<0.01$ & $\mathrm{P}>0.01$ \\
\hline & Methanol & $1800-2000$ & $10.00-93.33$ & $75 x-240.97$ & 13.040 & 105.988 & 0.210 \\
\hline & & & & & $\mathrm{P}>0.01$ & $\mathrm{P}<0.01$ & $p>0.01$ \\
\hline
\end{tabular}


Effects of the extracts of S. alba, C. papaya, M. charantia and C. annuum seeds on An. annularis:

The mortality range of An. annularis larvae for $S$. alba, C. papaya, M. charantia and C. annuum seed extracts varied from 10.00-96.67\%, 6.67-96.67\%, 13.33-96.67\% and 6.67-96.67\%, respectively. Chi square values at 0.01 level of significance showed that most of the extracts had insignificant values except the distilled water and 50\% ethanol extracts of $S$. alba and $M$. charantia, distilled water and methanol extracts of $C$. papaya and acetone extract of $C$. annuum seeds. ANOVA test showed that all the treatment values were significant and the replicate values were insignificant with all the seed extracts at 0.01 level excepting acetone extract of $S$. alba seeds for An. annularis.

Table 2. Toxicities of the extracts of Sinapis alba, Carica papaya, Momordica charantia and Capsicum annuum seeds on Culex quinquefasciatus larvae exposed for 24 hours.

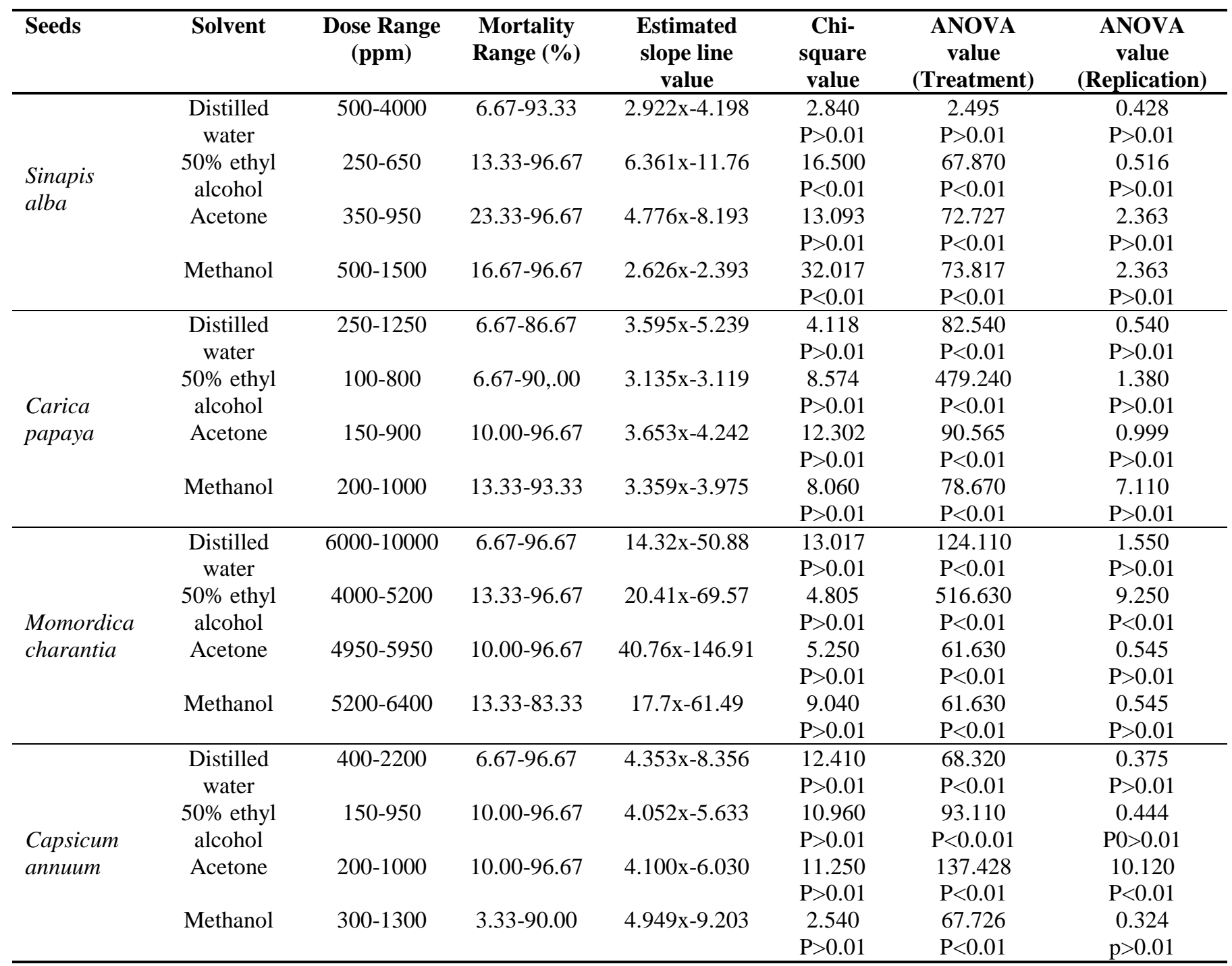

Effects of the extracts of $S$. alba, C. papaya, M. charantia and $C$. annuum seeds on $C x$. quinquefasciatus

The mortality range of $C x$. quinquefasciatus larvae varied from 6.67-96.67\%, 6.67-96.67\%, 6.6796.67\% and 3.33-96.67\% after treating with $S$. alba, C. papaya, M. charantia and C. annuum seed extracts, respectively. Chi square values indicated that all the seed extracts showed insignificant values 
except $50 \%$ ethyl alcohol and methyl extracts of $S$. alba seeds at 0.01 significance level. ANOVA test showed that all the treatment values were significant excepting the distilled water extract of $S$. alba and all the replicate values were insignificant with all the seed extracts excepting 50\% ethyl alcohol extract of $M$. charantia and acetone extract of $C$. annuum seeds at 0.01 level for $C x$. quinquefasciatus larvae.

In terms of $\mathrm{LC}_{50}$ values, the relative potency values of the distilled water, $50 \%$ ethyl alcohol, acetone and methanol extracts for An. annularis and $C x$. quinquefasciatus were calculated. The relative potency values in terms of $\mathrm{LC}_{50}$ values are given in Table 3 for both the mosquito larvae.

Table 3. The $\mathrm{LC}_{50}$ and Relative potency values of the distilled water, $50 \%$ ethyl alcohol, acetone and methanol extracts of S. alba, C. papaya, M. charantia and C. annuum seeds on An. annularis and Cx. quinquefasciatus larvae.

\begin{tabular}{|c|c|c|c|c|c|}
\hline \multirow[t]{2}{*}{ Seeds } & \multirow[t]{2}{*}{ Extracts } & \multicolumn{2}{|c|}{ An. annularis } & \multicolumn{2}{|c|}{ Cx. quinquefasciatus } \\
\hline & & $\mathbf{L C}_{50}(\mathbf{p p m})$ & Relative potency & $\mathrm{LC}_{50}(\mathrm{ppm})$ & Relative potency \\
\hline \multirow{4}{*}{$\begin{array}{l}\text { Sinapis } \\
\text { alba }\end{array}$} & Distilled water & 3431.791 & 3.087 & 1415.311 & 5.486 \\
\hline & $50 \%$ ethyl alcohol & 1038.363 & 10.202 & 432.996 & 17.931 \\
\hline & Acetone & 1254.810 & 8.442 & 569.701 & 13.628 \\
\hline & Methanol & 2269.975 & 4.667 & 770.250 & 10.080 \\
\hline \multirow{4}{*}{$\begin{array}{l}\text { Carica } \\
\text { papaya }\end{array}$} & Distilled water & 804.008 & 13.175 & 705.599 & 11.004 \\
\hline & $50 \%$ ethyl alcohol & 403.294 & 26.267 & 385.688 & 20.131 \\
\hline & Acetone & 573.241 & 18.479 & 341.003 & 22.768 \\
\hline & Methanol & 597.165 & 17.739 & 481.067 & 16.139 \\
\hline \multirow{4}{*}{$\begin{array}{l}\text { Momordica } \\
\text { charantia }\end{array}$} & Distilled water & 10593.241 & 1.000 & 7764.154 & 1.000 \\
\hline & $50 \%$ ethyl alcohol & 5017.710 & 2.111 & 4496.464 & 1.727 \\
\hline & Acetone & 5650.204 & 1.878 & 5353.759 & 1.450 \\
\hline & Methanol & 6075.204 & 1.744 & 5825.031 & 1.333 \\
\hline \multirow{4}{*}{$\begin{array}{l}\text { Capsicum } \\
\text { annuиm }\end{array}$} & Distilled water & 2173.632 & 4.873 & 1213.240 & 6.399 \\
\hline & $50 \%$ ethyl alcohol & 1311.538 & 8.077 & 420.967 & 18.444 \\
\hline & Acetone & 1604.852 & 6.601 & 490.454 & 15.830 \\
\hline & Methanol & 1905.692 & 5.559 & 770.601 & 10.075 \\
\hline
\end{tabular}

\section{Relative potency values of the extracts on Anopheles annularis:}

In case of An. annularis, it was observed in Table 3 that 50\% ethyl alcohol extract of C. papaya seeds was the most toxic having lowest $\mathrm{LC}_{50}$ value of $403.294 \mathrm{ppm}$ and relative potency value of 26.267 whilst the least toxic was the distilled water extract of $M$. charantia seeds with $\mathrm{LC}_{50}$ value 10593.241 ppm and relative potency value 1.00. The relative position of the four extracts of four seeds on the basis of their $\mathrm{LC}_{50}$ and relative potency values were in the order: $50 \%$ ethyl alcohol extrtact of C. papaya > acetone extract of $C$. papaya > methanol extract of $C$. papaya > distilled water extract of $C$. papaya $>$ $50 \%$ ethyl alcohol extract of $S$. alba $>$ acetone extract of $S$. alba $>50 \%$ ethyl alcohol extract of $C$. annuиm $>$ acetone extract of $C$. annuиm $>$ methanol extract of $C$. annuum $>$ distilled water extract of $C$. annuиm $>$ distilled water extract of $S$. alba $>$ methanol extract of $S$. alba $>50 \%$ ethyl alcohol extract of $M$. charantia $>$ acetone extract of $M$. charantia $>$ methanol extract of $M$. charantia $>$ distilled water extract of $M$. charantia. Of the seed extracts, the toxicity of the four plants was in the order: C. papaya $>C$. annuum $>S$. alba $>M$. charantia. The toxicity of the solvents of the four seeds was in the order: $50 \%$ ethyl alcohol $>$ acetone $>$ methanol $>$ distilled water.

\section{Relative potency values of the extracts on Culex quinquefasciatus:}

In $C x$. quinquefasciatus, the most and least toxic extracts were acetone extract of $C$. papaya and distilled water extract of $M$. charantia with LC $_{50}$ values of $341.003 \mathrm{ppm}$ and $7764.154 \mathrm{ppm}$, respectively and relative potency values 22.768 and 1.0, respectively. The relative position of the four extracts of four seeds, in terms of their $\mathrm{LC}_{50}$ and relative potency values, was in the order: acetone extrtact of $C$. 
papaya $>50 \%$ ethyl alcohol extract of $C$. papaya $>50 \%$ ethyl alcohol extract of C. annuum $>50 \%$ ethyl alcohol extract of $S$. alba > methanol extract of $C$. papaya $>$ acetone extract of $C$. annuum $>$ acetone extract of $S$. $a l b a>$ distilled water extract of $C$. papaya $>$ methanol extract of $S$. alba $>$ methanol extract of $C$. annuum > distilled water extract of $C$. annuum > distilled water extract of $S$. alba $>50 \%$ ethyl alcohol extract of $M$. charantia $>$ acetone extract of $M$. charantia $>$ methanol extract of $M$. charantia $>$ distilled water extract of $M$. charantia (Table 3).
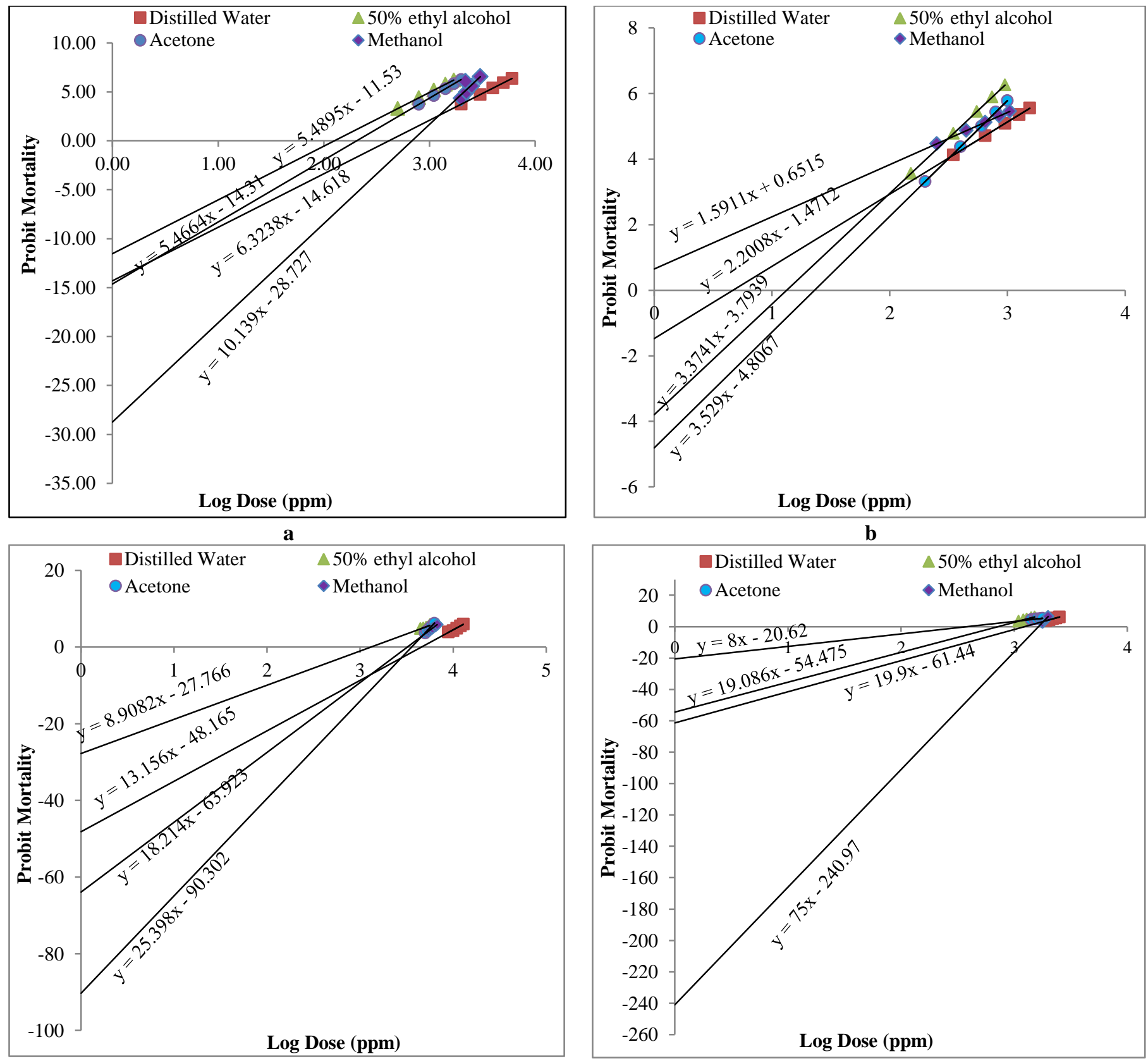

c

d

Fig. 1. Regression lines for determining the $\mathrm{LC}_{50}$ of distilled water, $50 \%$ ethyl alcohol, acetone and methanol extracts of Sinapis alba (A), Carica papaya (B), Momordica charantia (C), and Capsicum annuum (D) seeds on Anopheles annularis larvae after 24 hours of exposure. 
The trend of toxicity of seed extracts of the four experimental plants was in the order: C. papaya > C. annuun $>S$. alba $>M$. charantia. The trend of toxicity of the four solvents for the four seeds was in the order: $50 \%$ ethyl alcohol $>$ acetone $>$ methanol $>$ distilled water excepting C. papaya seeds, where, acetone seed extract was more toxic than $50 \%$ ethyl alcohol seed extract (Table 3).

During the present study the larvicidal activities of different solvents, such as distilled water, $50 \%$ ethyl alcohol, acetone, and methanol extracts of the dry seeds of S. Alba, C. Papaya, M. Charantia and $C$. annuum were bioassayed against the third and fourth instar larvae of An. annularis and $C x$. quinquefasciatus. Their toxicities varied with the dosages and also with experimental plants.

The $\mathrm{LC}_{50}$ value of the distilled water extract of $S$. alba seeds on An. annuularis was $3431.791 \mathrm{ppm}$, which was more or less similar to the findings of Bhuiyan (2013) with acetone and methanol extracts of Polygonum hydropiper seeds $\left(\mathrm{LC}_{50}=3265.356 \mathrm{ppm}\right.$ and $\mathrm{LC}_{50}=3355.353 \mathrm{ppm}$, respectively $)$ against $C x$. quinquefasciatus larvae. The $\mathrm{LC}_{50}$ of $50 \%$ ethyl alcohol extract of $S$. alba seeds was 1038.363 ppm, somewhat close to the findings of Shaktivadivel et al. (2012) with petroleum ether extract of Cipadessa baccifera leaf $\left(\mathrm{LC}_{50}=973.32 \mathrm{ppm}\right)$ against $C x$. pipiens larvae. The $\mathrm{LC}_{50}$ of acetone extract of $S$. alba seeds was $1254.810 \mathrm{ppm}$, which is quite similar to the findings of Nika (2015) with methanol extract of Brassica nigra seeds $\left(\mathrm{LC}_{50}=1396.927 \mathrm{ppm}\right)$ against $C x$. quinquefasciatus larvae and the $\mathrm{LC}_{50}$ of methanol extract of S. alba seeds was 2269.975 ppm, more or less similar to Akter (2009) with 100\% ethyl alcohol extract of Lagestroemia speciosa seeds $\left(\mathrm{LC}_{50}=2107.05 \mathrm{ppm}\right)$ against $C x$. quinquefasciatus larvae.

The $\mathrm{LC}_{50}$ value of the distilled water extract of $C$. papaya seeds on An. annularis was $804.008 \mathrm{ppm}$, which was more or less similar to the findings of Shaktivadivel et al. (2012) with petroleum ether extract of Cipadessa baccifera leaf $\left(\mathrm{LC}_{50}=973.32 \mathrm{ppm}\right)$ against $C x$. quinquefasciatus larvae. The $\mathrm{LC}_{50}$ of $50 \%$ ethyl alcohol extract of $C$. papaya seeds was 403.294 ppm, which is quite similar to the findings of the Bansal et al. (2014) with petroleum ether extract of Cleome viscose seeds $\left(\mathrm{LC}_{50}=301.9 \mathrm{ppm}\right)$ against $C x$. quinquefasciatus larvae. The $\mathrm{LC}_{50}$ of acetone extract of $C$. papaya seeds was 597.165 ppm, somewhat close to the findings of Nika (2015) with 50\% ethyl alcohol extract of Cuminum cyminum seeds $\left(\mathrm{LC}_{50}=\right.$ $543.523 \mathrm{ppm}$ ) against $C x$. quinquefasciatus larvae. The $\mathrm{LC}_{50}$ of methanol extract of $C$. papaya seeds was $573.241 \mathrm{ppm}$, which is more or less similar to the findings of Nika (2015) with 50\% ethyl alcohol extract of Cuminum cyminum seeds $\left(\mathrm{LC}_{50}=543.523 \mathrm{ppm}\right)$ against $C x$. quinquefasciatus larvae.

The $\mathrm{LC}_{50}$ value of the distilled water extract of $M$. charantia seeds on An. annularis was $10593.241 \mathrm{ppm}$, which was somewhat close to the finding of Aina et al. (2009) with distilled water extract of Jatropha curcas seeds $\left(\mathrm{LC}_{50}=12.00 \mathrm{mg} / \mathrm{ml}=12000 \mathrm{ppm}\right)$ against $A n$. gambiae larvae. The $\mathrm{LC}_{50}$ of $50 \%$ ethyl alcohol extract of M. charantia seeds was 5017.710 ppm, which was more or less similar to Bhuiya (2013) with the distilled water and 50\% ethyl alcohol extract of Albizzia procera and Polygonum hydropiper seeds $\left(\mathrm{LC}_{50}=4689.829\right.$ ppm and $\mathrm{LC}_{50}=5030.598 \mathrm{ppm}$ ) against $C x$. quinquefasciatus larvae. The $\mathrm{LC}_{50}$ of acetone extract of $M$. charantia seeds was $5650.191 \mathrm{ppm}$, which was somewhat close to the findings of Akter (2009) with 50\% ethyl alcohol extract of Lagestroemia speciosa seeds $\left(\mathrm{LC}_{50}=5286.27 \mathrm{ppm}\right)$ against Cx. quinquefasciatus larvae. The $\mathrm{LC}_{50}$ of methanol extract of $M$. charantia seeds was $6075.204 \mathrm{ppm}$, which was nearer to the findings of Nika (2015) with the distilled water extract of Albizzia lebbeck seeds $\left(\mathrm{LC}_{50}=6355.342 \mathrm{ppm}\right)$ against $C x$. quinquefasciatus larvae.

The $\mathrm{LC}_{50}$ value of the distilled water extract of $C$. annuum seeds on An. annularis was $2173.632 \mathrm{ppm}$, which was nearer to the findings of Hossain et al. (1998) with ethanol extract of Azadirachta indica seeds $\left(\mathrm{LC}_{50}=2100 \mathrm{ppm}\right)$ against $C x$. quinquefasciatus larvae. The $\mathrm{LC}_{50}$ of $50 \%$ ethyl alcohol extract of C. annuum seeds was $1311.538 \mathrm{ppm}$, more or less similar to the findings of Skaktivadivel et al. (2012) with ether extract of Clausena dentate leaf $\left(\mathrm{LC}_{50}=1435.40 \mathrm{ppm}\right)$ against $C x$. quinquefasciatus larvae. The $\mathrm{LC}_{50}$ of acetone extract of $C$. annuum seeds was $1604.852 \mathrm{ppm}$, which was quite similar to the findings of Bhuiyan (2013) with methanol extract of Albizzia procera seeds $\left(\mathrm{LC}_{50}=1575.808 \mathrm{ppm}\right)$ against $C x$. quinquefasciatus larvae. The 
$\mathrm{LC}_{50}$ of methanol extract of $C$. annuum seeds was 1905.692 ppm showing similarity with the findings of Nika (2015) with methanol extract of Trigonella foenum-graecum seeds $\left(\mathrm{LC}_{50}=1883.852 \mathrm{ppm}\right)$ against $C x$. quinquefasciatus larvae.
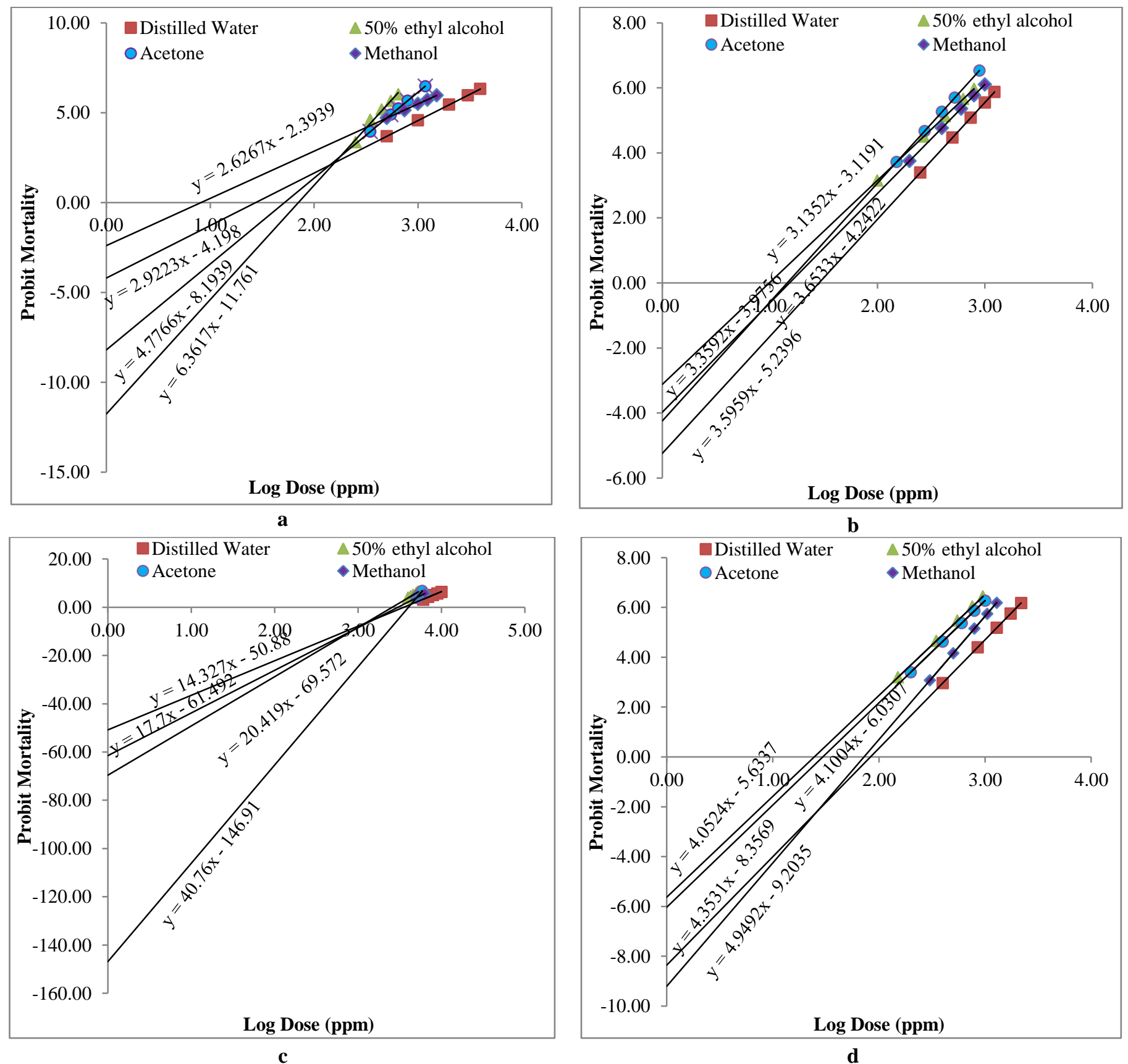

Fig. 2. Regression lines for determining the $\mathrm{LC}_{50}$ of distilled water, $50 \%$ ethyl alcohol, acetone and methanol extracts of Sinapis alba (A), Carica papaya (B), Momordica charantia (C), and Capsicum annuum (D) seeds on Culex quinquefasciatus larvae after 24 hours of exposure.

The $\mathrm{LC}_{50}$ value of the distilled water extract of $S$. alba seeds on Cx. quinquefasciatus larvae was 1415.311 ppm, which was more or less similar to the findings of Skaktivadivel et al. (2012) with ether extract of Clausena dentate leaf $\left(\mathrm{LC}_{50}=1435.40 \mathrm{ppm}\right)$ against $C x$. quinquefasciatus larvae. The $\mathrm{LC}_{50}$ of $50 \%$ ethyl 
alcohol extract of S. alba seeds was 432.996 ppm, somewhat close to the findings of Patil et al. (2014) with hexane extract of Gossypium hirsutum leaf $\left(\mathrm{LC}_{50}=401.03 \mathrm{mg} / \mathrm{L}=401.03 \mathrm{ppm}\right)$ against Ae. aegypti larvae. The $\mathrm{LC}_{50}$ of acetone extract of $S$. alba seeds was $569.701 \mathrm{ppm}$, quite similar to the findings of Nika (2015) with $50 \%$ ethyl alcohol extract of Cuminum cyminum seeds $\left(\mathrm{LC}_{50}=543.523 \mathrm{ppm}\right)$ against $C x$. quinquefasciatus larvae. The $\mathrm{LC}_{50}$ of methanol extract of $S$. alba seeds was $770.250 \mathrm{ppm}$, more or less similar to the findings of Nika (2015) with methanol extracts of Nigella sativa seeds $\left(\mathrm{LC}_{50}=793.250 \mathrm{ppm}\right)$ against $C x$. quinquefasciatus larvae.

The $\mathrm{LC}_{50}$ value of the distilled water extract of $C$. papaya seeds on Cx. quinquefasciatus was 705.599 ppm, which was more or less similar to Nika (2015) with methanol extract of Nigella sativa seeds $\left(\mathrm{LC}_{50}=793.981 \mathrm{ppm}\right)$ against $C x$. quinquefasciatus larvae. The $\mathrm{LC}_{50}$ of $50 \%$ ethyl alcohol extract of $C$. papaya seeds was $385.688 \mathrm{ppm}$, which is quite similar to the findings of Marmimuthu and Mohan (2014) with benzene and hexane extracts of Pithecellobium dulce seeds $\left(\mathrm{LC}_{50}=303.22 \mathrm{mg} / \mathrm{L}=303.22 \mathrm{ppm}\right.$ and $\mathrm{LC}_{50}=322.80 \mathrm{mg} / \mathrm{L}=322.80 \mathrm{ppm}$, respectively) against $C x$. quinquefasciatus larvae. The $\mathrm{LC}_{50}$ of acetone extract of $C$. papaya seeds was $341.003 \mathrm{ppm}$, somewhat close to the findings of Remia and Logaswamy (2010) with acetone extract of Lantana camara leaf $\left(\mathrm{LC}_{50}=356.70 \mathrm{ppm}\right)$ against Ae. aegypti larvae. The $\mathrm{LC}_{50}$ of methanol extract of $C$. papaya seeds $(481.067 \mathrm{ppm})$ was more or less similar to the findings of Patil et al. (2014) with ethyl acetate extract of Gossypium hirsutum leaf $\left(\mathrm{LC}_{50}=401.03 \mathrm{mg} / \mathrm{L}=404.03\right.$ ppm) against Ae. aegypti larvae.

The $\mathrm{LC}_{50}$ value of the distilled water extract of $M$. charantia seeds on $C x$. quinquefasciatus larvae was $7764.154 \mathrm{ppm}$ which was somewhat close to the findings of Akter (2009) with the distilled water extract of Swietenia mahogoni seeds $\left(\mathrm{LC}_{50}=6209.98 \mathrm{ppm}\right)$ against $C x$. quinquefasciatus larvae. The $\mathrm{LC}_{50}$ of $50 \%$ ethyl alcohol extract of $M$. charantia seeds was $4496.464 \mathrm{ppm}$, which was more or less similar to the findings Bhuiya (2013) with the distilled water extract of Albizzia procera seeds $\left(\mathrm{LC}_{50}=\right.$ $4689.829 \mathrm{ppm}$ ) against $C x$. quinquefasciatus larvae. The $\mathrm{LC}_{50}$ of acetone extract of $M$. charantia seeds was $5353.759 \mathrm{ppm}$, which was nearer to the findings of Akter (2009) with 50\% ethyl alcohol extract of Lagestroemia speciosa seeds $\left(\mathrm{LC}_{50}=5286.27 \mathrm{ppm}\right)$ against $C x$. quinquefasciatus larvae. The $\mathrm{LC}_{50}$ of methanol extract of $M$. charantia seeds was $5825.031 \mathrm{ppm}$, which was nearer to the findings of Nika (2015) with distilled water extract of Albizzia lebbeck seeds $\left(\mathrm{LC}_{50}=6355.342 \mathrm{ppm}\right)$ against $C x$. quinquefasciatus larvae.

The $\mathrm{LC}_{50}$ value of the distilled water extract of $C$. annuum seeds on $C x$. quinquefasciatus larvae was 1213.240 ppm, which was quite similar to the findings of Nika (2015) with methanol extract of Brassica nigra, seeds $\left(\mathrm{LC}_{50}=1396.927 \mathrm{ppm}\right)$ against $C x$. quinquefasciatus larvae. The $\mathrm{LC}_{50}$ of $50 \%$ ethyl alcohol extract of $C$. апnиum seeds was 420.967 ppm, more or less similar to the findings of Remia and Logaswamy (2010) with acetone extract of Lantana camara leaf $\left(\mathrm{LC}_{50}=356.70 \mathrm{ppm}\right)$ against Ae. aegypti larvae. The $\mathrm{LC}_{50}$ of acetone extract of $C$. annuum seeds was $490.967 \mathrm{ppm}$, quite similar to the findings of Patil et al. (2014) with hexane extract of Gossypium hirsutum leaf $\left(\mathrm{LC}_{50}=401.03 \mathrm{mg} / \mathrm{L}=401.03 \mathrm{ppm}\right)$ against Ae. aegypti larvae. The $\mathrm{LC}_{50}$ of methanol extract of $C$. annuum seeds was $770.601 \mathrm{ppm}$, showing similarity with of the findings of Nika (2015) with methanol extract of Nigella sativa $\left(\mathrm{LC}_{50}=793.981 \mathrm{ppm}\right)$ against $C x$. quinquefasciatus larvae.

The present finding has important implications on the practical control of mosquito larvae in polluted aquatic ecosystems. In view of residue problem in the environment and the development of insect resistance to synthetic insecticides, the recent trend is to explore plants to obtain the extracts that do not pose any residue problem, but are able to suppress unwanted populations. Further research will lead to improve formulations with enhanced activity which may become environmentally acceptable and replace objectionable conventional insecticides for mosquito control. 


\section{REFERENCES}

Ahmed, T. U. 1987. Checklist of mosquitoes of Bangladesh. Mosquito Systematics. 19: 191-204.

Aina, S. A., A. D. Nanjo, O. A. Lawal and K. Jonathan. 2009. Efficacy of some plant extracts on Anopheles gambiae mosquito larvae. Acad. J. Entomol. 2(1): 31-35.

Akter, H. 2009. Larvicidal activities of Lagerstroemia speciosa (Linn) Pers seed and Swietenia mahagoni (Jacq) seed kernel extracts against Culex sp. larvae. MS project. Department of Zoology, University of Chittagong, Bangladesh. $50 \mathrm{pp}$.

Ameen, M., A. K. A. Chowdhury, H. R. Khan and R. M. Shahjahan. 1983a. Insecticidal properties of Derris elliptica (Wall.) Benth. (Leguminosae: Papilionaceae) roots against the larvae of Culex fatigans (Diptera: Culicidae). Dhaka Univ. Stud. B. XXXI(1): 1-11.

Ameen, M., R. M. Shahjahan and H. R. Khan. 1983b. Toxicity of rotenone extracted from indigenous Derris roots on mosquito larvae. J. Bangladesh Acad. Sci. 7(1): 39-47.

Ameen, M., R. M. Shahjahan, H. R. Khan and A. K. A. Chowdhury. 1985. Larvicidal effects of indigenous Derris elliptica root on Aedes aegypti (Diptera, Culicidae). Int. Quarterly Entomol. 1: 39-43.

American Public Health Association (APHA). 2005. Standard methods for the examination of water and waste water. 21 st ed. Washington D.C., USA. 40 pp.

Bansal, K. S., K. V. Singh and S. Sharma. 2014. Larvicidal potential of wild mustard (Cleome viscose) and gokhra (Tribulus terrestris) against mosquito vectors in the semi-arid region of Western Rajasthan. J. Environ. Biol. 35: 327-332.

Bhuiyan, S. Y. 2013. Evaluation of toxic effects of six insecticides and three plant seed extracts against Culex quinquefasciatus Say (Diptera: Culicidae) larvae. MS Thesis, Department of Zoology, University of Chittagong. $115 \mathrm{pp}$.

Changbunjong, T., W. Wongwit, S. Leeming, S. Tongtokit and V. Deesin. 2010. Effect of extract of Solanum xanthocarpum against snails and mosquito larvae. Southeast Asian J. Trop. Med. Public Health. 41(2): 320-325.

El-Sheikh, T. M. Y., M. I. Hassan, W. A. Moselhy, M. S. Amer and A. Z. Shehata. 2011. Evaluation of the Cupressus sempersiens (Cupressaceae) extracts against the mosquito vector Culex pipiens $\mathrm{L}$. (Diptera: Culicidae). Egypt Acad. J. Biol. Sci. 4(1): 33-48.

Finney, D. J. 1971. Probit analysis. 3rd ed. Cambridge University Press, London, UK. 333 pp.

Fisher, R. A. and F. Yates. 1963. Statistical tables for Biological, Agricultural and Medicinal Research. 6th ed. Oliver and Boyd Ltd. Edinburgh, UK., pp. 47-50.

Hossain, M. I., M. Ameen, M. A. H. Mridha and A. J. Ferdous. 1998. Insecticidal action of neem seed extracts on the larvae of Culex quinquefasciatus Say (Diptera: Culicidae). J. Asia. Soc. Bangladesh Scg. 24(1): 119-125.

Kamaraj, C., A. Bagavaj, G. Elango, A. A. Zahir, G. Rajkumar and S. Mariamuthu. 2011. Larvicidal activity of medicinal plant extracts against Anopheles stephensi and Culex tritaeniorhunchus. Indian J. Med. Res. 134: 101-116.

Khan, H. R., H. Afia, J. I. Rahman and T. Tanjina. 2016. Larvicidal activity of neem (Azadirachta indica A. Juss) leaf extracts against the mosquito larvae of Culex quinquefasciatus (Say) (Diptera: Culicidae). J. Biodivers. Conserv. Bioresour. Manag. 2(2): 83-91. 
Khan, H. R., T. Tanjina, J. I. Rahman and H. Afia. 2017. Efficacy of fruit palp solvent extracts of Cassia fistula Linn. against the fourth instar larvae of the mosquito Culex quinquefasciatus Say. J. Asiat. Soc. Bangladesh, Sci. 43(1): 1-9.

Mansour, S. A., S. S. Messeha and S. M. Hamed. 1998. Botanical Biocides 5. Mosquitocidal activity of certain Nigella sativa constituents. J. Union Arab Biol. 10A: 45-63.

Marimuthu, G. and R. Mohan. 2014. Mosquito larvicidal and ovicidal properties of Pithecellobium dulce (Roxb.) Benth. (Fabaceae) against Culex quinquefasciatus Say (Diptera: Culicidae). J. Coastal Life Med. 2(4): 308-312.

Nasiruddin, M., M. A. Azadi and M. Akter. 2018. Performance evaluation of two plant parts in controlling Culex quinquefasciatus Say (Diptera: Culicidae) larvae. Bangladesh J. Environ. Sci. 35: 97-110.

Nika, S. 2015. Larvicidal efficacy of six plant seed extracts against Culex quinquefasciatus Say (Diptera: Culicidae) larvae. MS Thesis. Department of Zoology, University of Chittagong, Bangladesh. 127 pp.

Nikkon, F., Z. A. Saud, K. Hossain, M. S. Parrir and M. E. Haque. 2009. Larvicidal effects of stem and fruits of Duranta repens against the mosquito Culex quinquefasciatus. Int. I. Pharm. Tech. Res. 1(4): 1709-1713.

Patil, C. D., H. P. Borase, R. B. Salunkhe, R. K. Suryawanshi, C. P. Narkhade, B. K. Salunke and S. V. 2014. Mosquito larvicidal potential of Gossypium hirsutum (Bt cotton) leaves extracts against Aedes aegypti and Anopheles stephensi larvae. J. Arthropod-Borne Dis. 8(1): 91-101.

Remia, K. M. and S. Logoswamy. 2010. Larvicidal efficacy of leaf extract of two botanicals against the mosquito vector Aedes aegypti (Diptera: Culicidae). Indian J. Natl Prodts Resour. 1(2): 208-212.

Sesanti, H., A. Arsunan and H. Ishak. 2014. Potential test of papaya leaf and seed extract as larvicides against Anopheles mosquito larvae mortality. Int. J. Sci. Res. 4: 2250-3153.

Sakthivadivel, M., A. Eapen and A. P. Dash. 2012. Evaluation of toxicity of plant extracts against vector of Lymphatic filariasis, Culex quinquefasciatus. Indian J. Med. Res. 135: 397-400.

Thangaraj, B., R. Ravichandran and M. Alwarsamy. 2014. Mosquito larvicidal activity of Coriandrum sativum and Brassica nigra seed extract against the Filarial vector Culex quinquefasciatus. Int. J. Innovative Res. (Sci. Eng. Tech.) 3: 8632-8637.

Zannat, M. F., T. Akter and S. Ahmad. 2007. Larvicidal activity of fresh and rotten leaf extract of some indigenous plant against third instar larvae of Culex quinquefasciatus Say (Diptera: Culicidae). $J$. Asiat. Soc. Bangladesh Sci. 24(1): 119-125. 
